\title{
Assessment of genetic relationship in Persea spp by traditional molecular markers
}

\author{
J.C. Reyes-Alemán ${ }^{1}$, E. Valadez-Moctezuma² and A.F. Barrientos-Priego ${ }^{3}$ \\ ${ }^{1}$ Centro Universitario UAEM Tenancingo, Universidad Autónoma del Estado de México, \\ Tenancingo, Estado de México, México \\ ${ }^{2}$ Laboratorio de Biología Molecular, Departamento de Fitotecnia, \\ Universidad Autónoma Chapingo, Texcoco, Estado de México, México \\ ${ }^{3}$ Programa de Fruticultura, Departamento de Fitotecnia, \\ Universidad Autónoma Chapingo, Texcoco, Estado de México, México \\ Corresponding author: E. Valadez-Moctezuma \\ E-mail: evaladez@correo.chapingo.mx \\ Genet. Mol. Res. 15 (2): gmr.15027359 \\ Received August 4, 2015 \\ Accepted November 27, 2015 \\ Published April 4, 2016 \\ DOI http://dx.doi.org/10.4238/gmr.15027359
}

ABSTRACT. Currently, the reclassification of the genus Persea is under discussion with molecular techniques for DNA analysis representing an alternative for inter- and intra-specific differentiation. In the present study, the traditional random-amplified polymorphic DNA (RAPD) and the inter simple sequence repeat (ISSR) markers were used to determine the genomic relationship of different species and hybrids representative of the subgenera Eriodaphne and Persea in a population conserved in a germplasm bank. The data were analyzed statistically using multivariate methods. In the RAPD analysis, a total of 190 polymorphic bands were produced, with an average of 23.7 bands per primer, the percentage contribution of each primer was from 7.66 to 19.63; the polymorphic information content (PIC) ranged from 0.23 to 0.45 , with an average of 0.35 . In the ISSR analysis, a total of 111 polymorphic bands were considered, with an average of 18.5 bands per primer, the percentage contribution of each was from 11.83 to 19.57 ; the PIC ranged from 0.35 to 0.48 , with an average of 0.42 . The phenograms obtained in each technique showed the relationship among the accessions through the clusters formed. In general, 
both the techniques grouped representatives of the Persea americana races ( $P$. americana var. drymifolia, $P$. americana var. guatemalensis, and $P$. americana var. americana). However, it was not possible to separate the species of Persea used as reference into independent clades. In addition, they tended to separate the representatives of subgenera Eriodaphne and Persea.

Key words: Avocado; PCR; Genetic resources; Differentiation; Genomic relationship; Molecular markers

\section{INTRODUCTION}

Avocado (Persea americana Mill.) has distinct nutritional properties and cultural importance. In Mesoamerica, it was widely used and domesticated by indigenous populations, long before the arrival of European explorers (Galindo-Tovar et al., 2007). Smith (1966) reported the oldest evidence of its use by people in caves located in the central part of Mexico and in the valleys of Oaxaca roughly between 7000-8000 BC. Later, in the mid-sixteenth century, avocado was cultivated by the residents of Mexico and Peru (Popenoe, 1963; Storey et al., 1986). Avocado belongs to genus Persea, which is currently divided into the subgenera Persea and Eriodaphne (Kopp, 1966). "True" avocados, belonging to the subgenus Persea, have larger fruits compared to those of Eriodaphne.

There are some differences among the races of $P$. americana Mill. ( $P$. americana var. drymifolia, $P$. americana var. guatemalensis, and $P$. americana var. americana). They are widely distributed in Mesoamerica (Fiedler et al., 1998) and most of the commercial varieties known to date are found among them, although there are controversies regarding their differentiation owing to high variability in the progeny. It has been suggested that prior to the arrival of the Spanish people to America, the races were separated with little or no mobility because of topographical conditions, climatic barriers, and large seed size. Currently, the races in many regions of America have overlapped and numerous sample collections show a clear racial introgression (Gama-Campillo, 1994). The flowering habit and cross-pollination of avocado, coupled with its prolific form and a low fruit-set, are other factors that prevent the understanding of the lineage of current cultivars and races.

DNA markers have been used successfully to discern genealogies, design breeding strategies, and support systematization and conservation in germplasm banks (Zietkiewicz et al., 1994; Gilbert et al., 1999; Valadez-Moctezuma et al., 2014; Valadez-Moctezuma et al., 2015). Using these tools, races of $P$. americana and some hybrids have been distinguished (Davis et al., 1998; Clegg et al., 1999; Ashworth and Clegg, 2003). The aim of the present study was to determine the genomic relationship among different genotypes of avocado, including hybrids and an unidentified genotype (Persea sp), conserved ex situ in a germplasm bank. Two different traditional and molecular techniques were used to better characterize each genotype to ensure their best use.

\section{MATERIAL AND METHODS}

\section{Persea genotypes}

Five representative species of the subgenus Eriodaphne, five of the subgenus Persea, four genotypes of $P$. americana var. americana, 10 genotypes of $P$. americana var. guatemalensis, 34 of $P$. americana var. drymifolia, 4 hybrids of $P$ ersea, and an unidentified genotype called "Persea 
sp" were used as references (Table 1). Most of the materials used are preserved ex situ in the CICTAMEX germplasm bank property of the Fundación Salvador Sánchez Colín, CICTAMEX S.C. in Coatepec Harinas, Estado de México; however, some materials were collected in situ.

Table 1. Persea spp genotypes considered in the study, key genotype, origin, genotype name, number in the germplasm bank, specie/subgenus and unidentified genotype.

\begin{tabular}{|c|c|c|c|c|c|}
\hline & Key genotype & Origin & Genotype name & Number in bank & Specie/subgenus \\
\hline 1 & $\mathrm{CH}$-Ver-1* & Veracruz, México & Persea sp & - & Probably Eriodaphne \\
\hline 2 & $\mathrm{CH}-\mathrm{Ver}-2$ & Veracruz-Chocamán & Parvifolia & - & P. parvifolia/Eriodaphne \\
\hline 3 & $\mathrm{CH}-\mathrm{C}-30$ & Veracruz & Cinerascens & - & P. cinerascens/Eriodaphne \\
\hline 4 & CH-Ch5 & Chile & Meyeniana & - & P. meyeniana/Eriodaphne \\
\hline 5 & CH-Ch-4 & Chile & Lingue 32 & 32 & P. lingue/Eriodaphne \\
\hline 6 & CH-Ver-3 & Veracruz-Huatusco & Floccosa $\mathrm{H}$ & - & P. longipes/Eriodaphne \\
\hline 7 & $\mathrm{CH}-\mathrm{I}-3$ & Veracruz & Floccosa 10 & 10 & P. floccosa/Persea \\
\hline 8 & CH-GU-1 & Guatemala & Shiedeana-Otrabanda & 17 & P. schiedeana/Persea \\
\hline 9 & $\mathrm{CH}-\mathrm{I}-4$ & Israel & Nubigena $1 / 7$ & 11 & P. nubigena/Persea \\
\hline 10 & CH-Chis-1 & Chiapas, México & Steyermarkii 155 & 232 & P. steyermarkii/Persea \\
\hline 11 & $\mathrm{CH}-\mathrm{I}-2$ & Chiapas & Gigantea & 3 & P. gigantea/Persea \\
\hline 12 & $\mathrm{CH}-\mathrm{I}-6$ & Israel & Antigua 19 & 14 & P. americana var. americana/Persea \\
\hline 13 & CH-G-49 & México & Tetiz 1 & 77 & $"$ \\
\hline 14 & $\mathrm{CH}-\mathrm{CR}-28$ & Costa Rica & Marichal & 102 & " \\
\hline 15 & CH-G-48 & México & Tetiz 2 & 79 & " \\
\hline 16 & CH-G-10 & México & Olanca 2S3 & 80 & P. americana var. guatemalensis/Persea \\
\hline 17 & CH-GU-16 & Guatemala & Miramundo & 55 & " \\
\hline 18 & CH-G-9 & México & Olanca & 25 & " \\
\hline 19 & CH-GU-5 & Guatemala & Palestre & 34 & " \\
\hline 20 & CH-G-15 & México & Larrainzar 1 & 54 & " \\
\hline 21 & $\mathrm{CH}-\mathrm{GU}-17$ & Guatemala & Teni & 56 & " \\
\hline 22 & CH-G-7 & México & Sn Cr Mer 7s1 & 60 & " \\
\hline 23 & $\mathrm{CH}-\mathrm{C}-43$ & México & Comcar 1 & 33 & " \\
\hline 24 & CH-G-4 & México & Sn Cr Mer 4S2 & 61 & $"$ \\
\hline 25 & CH-G-24 & México & Amatenango S1 & 94 & " \\
\hline 26 & $\mathrm{CH}-\mathrm{C}-62$ & Estados Unidos & M. Grande & 19 & P. americana (híbrido)/Persea \\
\hline 27 & $\mathrm{CH}-\mathrm{C}-58$ & México & $230 \mathrm{ptb}$ & 51 & " \\
\hline 28 & $\mathrm{CH}-\mathrm{CR}-44$ & Costa Rica & Cima de Copey & 78 & " \\
\hline 29 & $\mathrm{CH}-\mathrm{C}-60$ & México & $24 \mathrm{ptb}$ & 87 & " \\
\hline 30 & $\mathrm{CH}-\mathrm{I}-7$ & Israel & Ettinger & 99 & P. americana var. drymifolia/Persea \\
\hline 31 & $\mathrm{CH}-\mathrm{C}-61$ & México & La Meza & 185 & " \\
\hline 32 & $\mathrm{CH}-\mathrm{Ch}-3$ & Chile & Negra la Cruz & 221 & " \\
\hline 33 & CH-Ch-2 & Chile & Fuerte Negro & 223 & " \\
\hline 34 & $\mathrm{CH}-\mathrm{C}-63$ & México & Tepetl & 46 & " \\
\hline 35 & $\mathrm{CH}-\mathrm{C}-43$ & México & Lonjas & 36 & " \\
\hline 36 & $\mathrm{CH}-\mathrm{C}-17-\mathrm{b}$ & México & Príncipe Negro 1 & 217 & " \\
\hline 37 & $\mathrm{CH}-\mathrm{C}-57$ & México & Ixtapan del O & 138 & " \\
\hline 38 & CH-P-31 & México & Telez 1 & 38 & " \\
\hline 39 & CH-G-86 & México & Mantequilla 1 & 37 & " \\
\hline 40 & CH-E-1 & Ecuador & Guay1 & 41 & " \\
\hline 41 & $\mathrm{CH}-\mathrm{Crm}-98$ & México & Portainjerto & 98 & " \\
\hline 42 & $\mathrm{CH}-\mathrm{C}-50 \mathrm{~b}$ & México & S Ag Negro & 96 & " \\
\hline 43 & $\mathrm{CH}-\mathrm{Crm}-97$ & México & CRM (Criollo Coatepec) & 97 & " \\
\hline 44 & CH-C-5 & México & Temascaltepec 3S4 & 73 & " \\
\hline 45 & $\mathrm{CH}-\mathrm{C}-2 \mathrm{a}$ & México & Malinaltenango & 84 & " \\
\hline 46 & CH-C-38 & México & Pintle 2 & 86 & " \\
\hline 47 & $\mathrm{CH}-\mathrm{C}-43 \mathrm{~b}$ & México & S Lonjas & 90 & " \\
\hline 48 & $\mathrm{CH}-\mathrm{C}-52 \mathrm{~b}$ & México & S Parque Timb & 91 & " \\
\hline 49 & $\mathrm{CH}-\mathrm{C}-50-\mathrm{a}$ & México & S Ag Negro (A. Negro) & 115 & " \\
\hline 50 & $\mathrm{CH}-\mathrm{E}-2$ & Ecuador & Guay III & 157 & " \\
\hline 51 & $\mathrm{CH}-\mathrm{P}-3$ & México & Tlacolula 3S2 & 161 & " \\
\hline 52 & CH-G-15 & México & Larrainzar 2 & 172 & " \\
\hline 53 & $\mathrm{CH}-\mathrm{P}-3$ & México & Tlacolula 86 & 177 & " \\
\hline 54 & $\mathrm{CH}-\mathrm{C}-22$ & México & Almoloya & 183 & " \\
\hline 55 & $\mathrm{CH}-\mathrm{C}-50-\mathrm{b}$ & México & Ag Negro & 188 & " \\
\hline 56 & $\mathrm{CH}-\mathrm{C}-19$ & México & Mantequilla 2 & 191 & " \\
\hline 57 & CH-G-26 & México & Amatenango S4 & 202 & " \\
\hline 58 & $\mathrm{CH}-\mathrm{C}-10 \mathrm{~b}$ & México & Tochimilco 1 & 209 & " \\
\hline 59 & CH-C-12 & México & Tochimilco 3 & 210 & " \\
\hline 60 & $\mathrm{CH}-\mathrm{C}-13$ & México & Tochimilco 4 & 211 & " \\
\hline 61 & $\mathrm{CH}-\mathrm{C}-14 \mathrm{a}$ & México & Tochimilco 5b & 214 & " \\
\hline 62 & CH-C-17-a & México & Principe Negro 2 & 216 & " \\
\hline 63 & CH-C-18 & México & Aquijic & 220 & " \\
\hline
\end{tabular}

*Unidentified genotype. 


\section{Development of molecular markers}

Genomic DNA was extracted from young leaves $(200 \mathrm{mg})$ using a slightly modified cetyltrimethylammonium bromide method (Saghai-Maroof et al., 1984). Genetic markers were developed using random-amplified polymorphic DNA (RAPD) and the inter simple sequence repeat (ISSR) (with anchor) techniques, both of which scan the whole genomes (Fontaine et al., 2004; Valadez-Moctezuma et al., 2014; Valadez-Moctezuma et al., 2015). Polymerase chain reaction (PCR) for RAPD comprised of $100 \mathrm{ng}$ genomic DNA, $1.5 \mathrm{U}$ Taq DNA polymerase (Fermentas, USA), $200 \mathrm{mM}$ dNTPs, 1X Taq buffer, $2.0 \mathrm{mM} \mathrm{MgCl}_{2}$, and $20 \mathrm{pM}$ primer in a $25-\mu \mathrm{L}$ total volume. The same components were used for ISSR but the amount of DNA and concentration of $\mathrm{MgCl}_{2}$ was $50 \mathrm{ng}$ and $3.0 \mathrm{mM}$, respectively. PCR was performed in a thermocycler Gene Amp PCR System $2700^{\circledR}$ (Applied Biosystems, USA) using the following programs: for RAPD, 1 min at $94^{\circ} \mathrm{C}$ followed by 35 cycles at $94^{\circ} \mathrm{C}$ for $30 \mathrm{~s}, 40^{\circ} \mathrm{C}$ for $30 \mathrm{~s}$, and $72^{\circ} \mathrm{C}$ for $1.5 \mathrm{~min}$, and a final extension at $72^{\circ} \mathrm{C} \mathrm{for}$ $2.5 \mathrm{~min}$; for ISSR, $1 \mathrm{~min}$ at $94^{\circ} \mathrm{C}$ followed by 38 cycles at $94^{\circ} \mathrm{C}$ for $30 \mathrm{~s}, 48^{\circ} \mathrm{C}$ for $30 \mathrm{~s}$, and $72^{\circ} \mathrm{C}$ for $2 \mathrm{~min}$, and a final extension of $72^{\circ} \mathrm{C}$ for $2.5 \mathrm{~min}$. The PCR primers used are shown in Table 2. PCR products were electrophoresed on $8 \%$ polyacrylamide gels (29:1); using1-kb DNA molecular weight marker (Gibco, USA) as a reference. The gel electrophoresis was done at 280 volts for approximately $2.5 \mathrm{~h}$ in $1 \mathrm{X}$ TBE buffer; the gels were stained with $0.2 \% \mathrm{AgNO}_{3}$ according to the standard protocol (Sambrook et al., 1989) and documented using the Kodak Digital Science 1D V.2.0.3 system (Eastman Kodak Company, New Haven, CT, USA).

Table 2. Primers used for DNA markers in Persea spp, type marker, primer key, locus/DNA bands, PIC, and RP.

\begin{tabular}{|c|c|c|c|c|}
\hline Type marker & Primer key & Locus/DNA bands & PIC & RP \\
\hline \multirow[t]{10}{*}{ RAPD } & A15 & 17 & 0.44 & 9.33 \\
\hline & $\mathrm{C} 8$ & 26 & 0.45 & 16.6 \\
\hline & C10 & 30 & 0.23 & 8.19 \\
\hline & C13 & 17 & 0.33 & 6.76 \\
\hline & E7 & 29 & 0.42 & 13.9 \\
\hline & E14 & 22 & 0.41 & 11.04 \\
\hline & E16 & 25 & 0.26 & 0.38 \\
\hline & E18 & 24 & 0.29 & 6.57 \\
\hline & Total & 190 & 2.83 & 72.77 \\
\hline & Average & 23.75 & 0.35375 & 9.09625 \\
\hline \multirow[t]{8}{*}{ ISSRs* $^{*}$} & $\mathrm{AC}(\mathrm{GACA}) 4$ & 18 & 0.47 & 9.71 \\
\hline & DBDA $(C A)_{7}$ & 15 & 0.48 & 8.1 \\
\hline & $(\mathrm{AC})_{8} \mathrm{YG}$ & 20 & 0.42 & 8.16 \\
\hline & $(\mathrm{GA})_{8} \mathrm{YC}$ & 18 & 0.42 & 9.81 \\
\hline & $(\mathrm{TCC})_{5} \mathrm{RY}$ & 18 & 0.35 & 6.16 \\
\hline & $(\text { GACA })_{4}{ }^{* *}$ & 22 & 0.4 & 10.22 \\
\hline & Total & 111 & 2.54 & 52.16 \\
\hline & Average & 18.5 & 0.42 & 8.69 \\
\hline
\end{tabular}

${ }^{*} \mathrm{~B}=\mathrm{G}, \mathrm{T}, \mathrm{C} ; \mathrm{D}=\mathrm{G}, \mathrm{A}, \mathrm{T} ; \mathrm{Y}=\mathrm{C}, \mathrm{T} ; \mathrm{R}=\mathrm{A}, \mathrm{G}$ anchored primers, ${ }^{* *}$ primer without an anchor.

\section{Statistical analysis}

Only the consistent and reproducible RAPD and ISSR amplified bands were considered for the analysis, in order to ensure the exclusion of gel artifacts. Polymorphic DNA bands were scored as discrete variables, " 1 " for the presence of a band and " 0 " for its absence, which were transformed into a binary character matrix. Subsequently, the data were processed with the FreeTree software (Version 0.9.1.5) (Pavlièek et al., 1999) to produce a genetic distance matrix using Nei and Li/Dice similarity coefficient. The resulting matrix was computed using the unweighted pair group method 
with arithmetic mean (UPGMA) to construct the phenogram with 1000 bootstrap replicates. Tree View 1.6.6 software was used to display the obtained tree (Hampl et al., 2001). The Mantel test was employed to compare the correlation between the distance matrices obtained with the RAPD and ISSR.

The ability of the most informative primers to differentiate between the accessions was assessed by the estimation of their PIC and resolving power (Rp). The PIC was calculated using the following formula described by Roldán-Ruiz et al. (2000):

$$
P I C i=2 f i(1-f i)
$$

where PICi was the polymorphic information content of the primer i, fi was the frequency of the bands present, and (1 - fi) was the frequency of the absent bands. The maximum value of PIC for dominant markers was 0.5 (De Riek et al., 2001). Rp was calculated (Prevost and Wilkinson, 1999) according to the following formula (Gilbert et al., 1999):

$$
\mathrm{Rp}=\sum \mathrm{Ib}
$$

where Ib represented the information band and was calculated using the formula:

$$
\mathrm{Ib}=1-(2 \mathrm{x}|0.5-\mathrm{p}|)
$$

where $\mathrm{p}$ was the proportion of accessions containing B and I was the percentage of polymorphic bands.

\section{RESULTS}

The DNA extracted from the studied samples was determined to be appropriate for RAPD and ISSR analyses. The photometric measurement quotient, $\mathrm{OD}_{260 / 280}$, of the DNA varied between 1.6 and 1.8, indicating acceptable quality of genomic DNA. Moreover, the DNA yield from $200 \mathrm{mg}$ young leaf tissue was approximately $50 \mathrm{ng} / \mu \mathrm{L}$. Both the employed DNA marker systems were sufficiently informative. The size of the PCR products considered for the RAPD analysis ranged between 350 and $2500 \mathrm{bp}$. In this analysis, a total of 190 amplified bands were considered, all of which were polymorphic; an average of 23.7 polymorphic bands were obtained per primer (Table 2) and the percentage contribution of each primer varied from 7.66 for the primer $\mathrm{C} 13$ to 19.63 for C8. The PIC ranged from 0.23 for the primer $\mathrm{C} 10$ to 0.45 for $\mathrm{C} 8$, with an average of 0.35 . Among the RAPD primers used, C8 was the most informative. The estimated Rp values exhibited a total rate of 72.77 and ranged from 0.38 (E16) to 16.6 (C8), with an average of 9.0 (Table 2). Moreover, C8 primer seemed to be the most efficient for assessing the genetic diversity as it presented the highest Rp value. The six ISSR primers produced 111 bands; all the bands were polymorphic and were amplified at an average of 18.5 bands per primer and the percentage contribution of the primers varied from 11.83 for the (TCC) $)_{5}$ RY primer to 19.57 for the AC (GACA) ${ }_{4}$ primer (Table 2). The size of the PCR products considered in the analysis ranged between 350 and $2500 \mathrm{bp}$. The PIC ranged from 0.35 for $(T C C)_{5} R Y$ to 0.48 for $\mathrm{DBDA}(\mathrm{CA})_{7}$ with an average of 0.42 . Among the ISSR primers used, the DBDA $(C A)_{7}$ primer was the most informative. The Rp values estimated for this marker system had a total rate of 52.16 and ranged from 6.16 for (TCC) $)_{5}$ RY to 10.22 for $(\mathrm{GACA})_{4}$, with an average of 8.69 (Table 2). Also, the primer (GACA) ${ }_{4}$ (the primer without an 
anchor) seemed to be the most efficient for assessing the genetic diversity as it presented a high rate of $\mathrm{Rp}$ (Table 2).

\section{Genetic similarities and relationships among accessions}

Estimates of genetic relationships between the accessions were obtained from the marker data using the Dice similarity coefficient (Pavlíèek et al., 1999). The UPGMA analysis confirmed the genetic divergence described above (Figures 1 and 2). The phenograms exhibited seven main groups ( $A, B, C, D, E, F$, and $G$ ). Furthermore, all the genotypes could be distinguished from each other suggesting a high level of genetic variation among the studied Persea accessions. The phenogram constructed with the RAPD markers (Figure 1) provided information equivalent to that obtained by using the ISSR markers (Figure 2). Reference species and races dispersed within the clade of the subgenus Persea are usually held together but also distributed throughout the clade, indicating the presence of DNA fragments common between the species and races representative of the subgenus. The 63 genotypes in the phenogram of RAPD were distributed as follows: group A comprised of the genotypes of the Mexican race ( $P$. americana var. drymifolia), group $\mathrm{B}$ of the Guatemalan and Antillean races ( $P$. americana vars. americana and guatemalensis), P. nubigena (Nubigena 1/7) and $P$. steyermarkii (Steyermarkii 155), group C comprised of a small group of Mexican races; the genotype Malinaltenango, an individual of the Mexican race without predefined taxonomic position, which joined the group of $P$. americana var. drymifolia (Mexican) based on ISSR, was located in group D. Group E was formed by four of the five species representative of the subgenus Eriodaphne namely, P. lingue (Lingue32), P. longipes (Floccosa H), P. cinerascens (Cinerascens), and P. meyeniana (Meyeniana); the F group was formed by $P$. parvifolia (Parvifolia) subgenus Eriodaphne and $P$. schiedeana (Shiedeana-Otrabanda), subgenus Persea. The last group (G) was represented by the unidentified Persea sp.

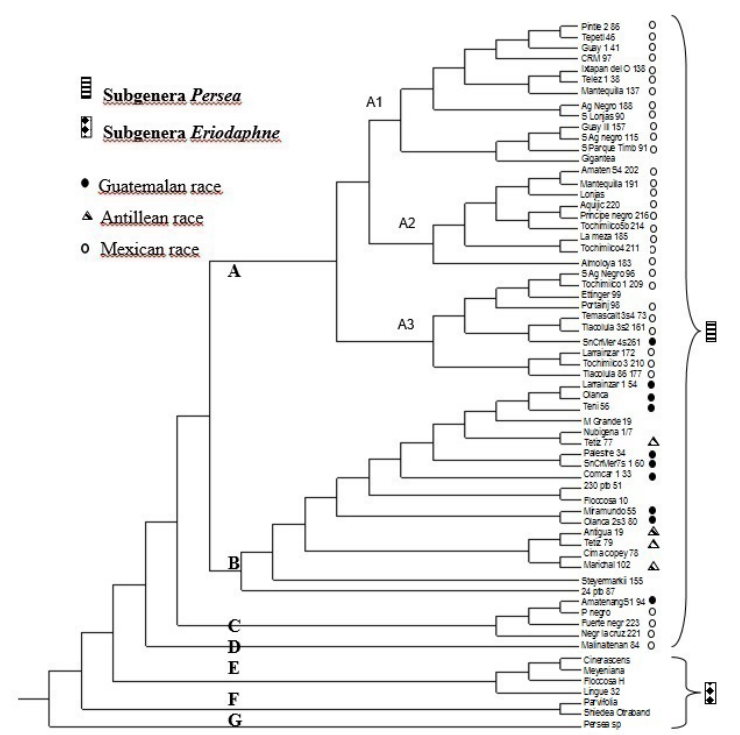

Figure 1. UPGMA grouping of accessions of Persea spp analyzed with RAPD profiles, distancing Nei and Li/Dice and bootstrapping 1000 repetitions. 


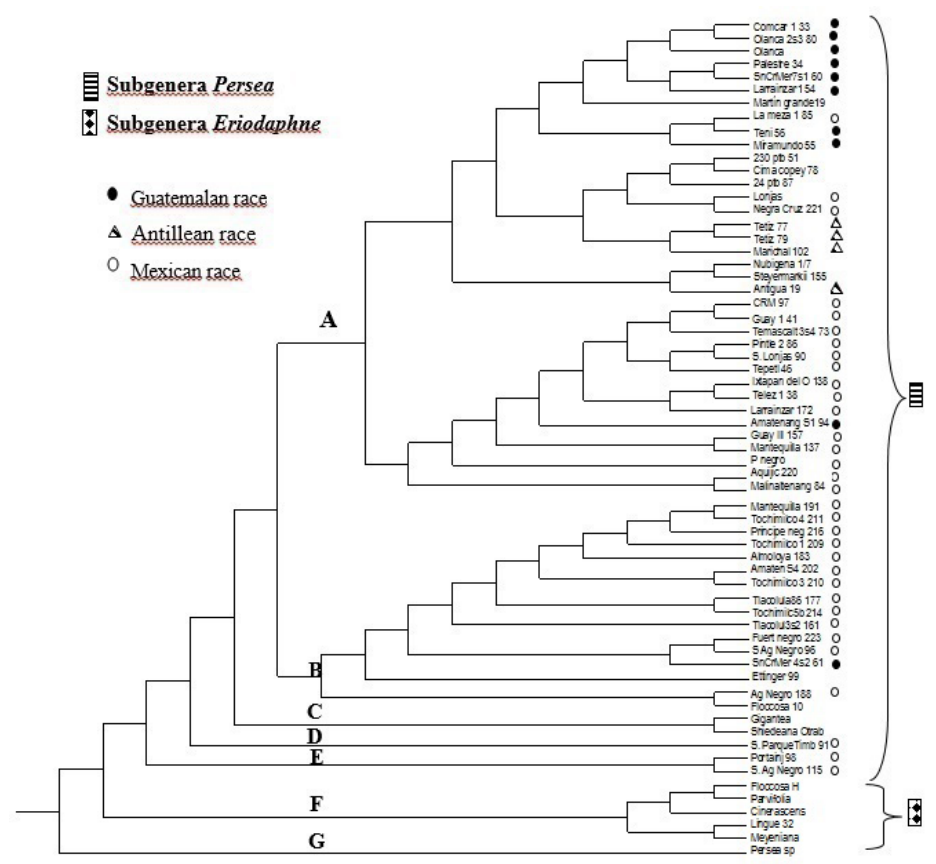

Figure 2. UPGMA grouping of accesions of Persea spp analyzed with ISSR profiles, distancing Nei and Li/Dice and bootstrapping 1000 repetitions.

In the phenogram constructed using the ISSR data (Figure 2), the 63 genotypes were also distributed into seven major groups. Group A comprised the Guatemalan and Antillean races, and some Mexican race genotypes as well as $P$. nubigena (Nubigena $1 / 7$ ) and $P$. steyermarkii (Steyermarkii 155). Group B comprised of most of the genotypes of the Mexican race $(P$. americana); $P$. gigantea (Gigantea) and $P$. schiedeana (Shiedeana-Otrabanda) were located in group C; in groups D and E, the Timb 91, Porta injerto 98, and S Ag negro-115 genotypes were located. Group F consisted of the five species of the subgenus Eriodaphne, $P$. lingue (Lingue32), $P$. longipes (Floccosa H), P. cinerascens (Cinerascens), P. meyeniana (Meyeniana), and P. parvifolia (Parvifolia). Group G was represented only by Persea sp, as in the RAPD analysis.

\section{DISCUSSION}

The ISSR technique is known to detect conserved amplicons located between the microsatellites of the same type; if the fragments correspond in size in individuals being compared, the likelihood of those individuals having a close relationship increases. Using this technique, it was also evident that the three horticultural varieties of $P$. americana usually stayed together throughout the clade; the closeness between the Antillean and Guatemalan races was also demonstrated by the representative species used.

The hybrid genotypes, M. Grande (G755), obtained by a cross between $P$. schiedeana and the Guatemalan race, had a marked resistance to root rot (Ellstrand et al., 1986), genotypes 230 ptb (obtained by segregation of the commercial variety Colin V-33) and 24 ptb (obtained by segregation 
of $P$. americana var. drymifolia) that were both tolerant to soil salinity (López et al., 1993), and the hybrid, Costa Rica Cima de Copey were all generated by selections within $P$. americana and were pooled between the Guatemalan and Antillean races, with both the marker types (Figures 1 and 2). In the study, the Guatemalan accessions, Olanca 2S3, Miramundo, Olanca, Palestre, Larrainzar 1, Teni, SnCrMer 7s1, Comcar 1, SnCrMer 4S2, and Amatenango S1, were also located near those. The Mantel test indicated a significant and positive correlation $(r=0.201, P<0.009)$ between the linear RAPD and ISSR individual pairwise genetic distance matrices.

Recent studies on the genetic diversity of the genus Persea have shown the efficacy of molecular techniques in estimating the genetic relationships among avocado genotypes (GutiérrezDíez et al., 2009; Cuiris-Pérez et al., 2009; Galindo-Tovar et al., 2011; Abraham and Takrama, 2013; Reyes-Alemán et al., 2013). Results obtained with the techniques used in this study, applied to the representatives of the subgenera Persea and Eriodaphne revealed a tendency to separate the genotypes of both the subgenera; this separation was more evident with the ISSR when compared to the RAPD technique. Remarkably, 301 DNA fingerprints were considered for the analyses of which 221 were shared by the 63 genotypes used. Furthermore, all of those were polymorphic. Representatives of the Eriodaphne group showed 67 monomorphic fingerprints in their own group while those of Persea showed 13, characteristic of the respective groups (data not shown). These few monomorphisms caused the differences that separated the genotypes into different clades. Based on the morphological characters, Eriodaphne and Persea have been reported as two subgenera within the genus Persea (Kopp, 1966). In the last decade, separating the genus based on differences in morphological as well as in the ITS sequences has been proposed (Campos et al., 2007). However, its taxonomic nomenclature is yet considered difficult because of the differences in ITS sequences, which are not entirely exclusive (Rohwer et al., 2009). The latter observation was also reflected in our results, because even though representatives of both the subgenera demonstrated a tendency to be separate in the phenograms, the amount of shared fragments (221) was higher than those stored for each subgenus (67 and 13). Another clear observation in this study was that $P$. floccosa, $P$. schiedeana, $P$. nubigena, $P$. steyermarkii, and $P$. gigantea were not separated in specific clades but were distributed in a large clade of $P$. americana. This behavior assumes that differences at the DNA level were not sufficient between these species to keep them in independent groups. The other genotypes (hybrid) were also distributed throughout the Persea clade, suggesting that they also maintained close genetic relationship. Differences between the races have been discussed by several authors (Furnier et al., 1990; Fiedler et al., 1998; Ashworth and Clegg, 2003). The present study indicates a close relationship between the Guatemalan and Antillean races, as reported by Bufler and Ben- Ya'acov (1992) and Mhameed et al., (1997) However, there was a trend of mixing between the races due to the proximity of the genotypes capable of interracial hybridization. This observation was also made by Chen et al. (2008). It has been suggested that $P$. americana has contributions from other species of Persea (Williams 1977a; Campos et al., 2007). This was also evident from the clusters in Figures 1 and 2, where the horticultural races could be observed to mix with $P$. steyermarkii and $P$. nubigena, which are wild species of the mountainous region of Chiapas (Mexico) and share morphological similarities, such as rudimentary little fruit pulp, leathery leaves, erect habit, and large-sized tree. Both the species were closely related to the Guatemalan race, based on the observations made earlier (Williams, 1977b; Furnier et al., 1990). This genetic contribution from the currently recognized Persea species is one of the reasons why its classification is not clear.

The genotype Persea sp, collected from Veracruz (Mexico), has not yet been identified, but 
shares morphological characteristics with Eriodaphne, such as lanceolate, leathery leaf, strong aroma on crushing, and "aguacatillo" type fruit, indicating the possibility of wild and unknown new species or hybrids, as reported by Lorea-Hernández (2005). This accession could be related to $P$. primatogena and $P$. parvifolia, two native Persea species also found in Veracruz and described by Williams (1977b).

$P$. schiedeana is a species with dense pubescence on their structures (Williams, 1977b). Its most distinctive morphological features include rigid and wide scales on its buds and short, straight, rigid, and persistent pubescence of gineceo (Scora et al., 2002). This species is capable of hybridizing with $P$. americana because of sexual and vegetative compatibility. Based on the analysis and location in the phenograms, there was a similarity with Eriodaphne genotypes, although, it is currently classified within Persea. Both the subgenera share the same distribution in America as indicated by Rohwer et al. (2009) and this is, perhaps due to the likeness in the two subgenera.

There are genotypes related to avocado that still need to be defined, such as "aguacatillos" and/or "cascarudos" from warm southern regions of Estado de México. Efforts for breeding could unravel genes saved in native populations, because if a local population represents a contribution to the genus diversity, then the population conserved in a germplasm collection, originated at different times and in different places, gains a higher value. This study helped in identifying the genomic relationships that germplasm accessions maintain and also their diversity. The genotypes used have different origins, and it could be possible to infer differences between the groups based on geographical confinement due to its origin as was suggested by Chen et al. (2009). In the past, this argument forced the designation of specific sites for the conservation of avocado collections from temperate climate and other warm weather in the CICTAMEX SC gene bank which are known sites of high and low elevation (López-López et al., 1997).

RAPD and ISSR markers were efficacious in demonstrating that the genotypes of Persea species and races of $P$. americana preserved in the germplasm bank were interrelated and had the ability to form new combinations. The RAPD and ISSR markers provided data that grouped the studied genotypes. DNA fingerprints separated the genotypes and classified them into Persea and Eriodaphne. The dispersed location of the genotypes of drymifolia, americana, and guatemalensis varieties within the clade of $P$. americana suggested a constant hybridization between the horticultural races. The unidentified genotype, referred to in this work as Persea sp, was kept separate from the genotypes of the subgenera Persea and Eriodaphne.

\section{Conflicts of interest}

The authors declare no conflict of interest.

\section{ACKNOWLEDGMENTS}

We thank Consejo Nacional de Ciencia y Tecnología (CONACyT) (account \#36110), Fundación Salvador Sánchez Colín CICTAMEX-SC, Universidad Autónoma Chapingo (UACH), and Universidad Autónoma del Estado de México (CUT-UAEM-Tenancingo) for funding and support.

\section{REFERENCES}

Abraham JD and Takrama JF (2013). Morphological and genetic diversity of Persea americana Mill. (Avocado) in two regions of Ghana. Conference on International Research on Food Security, Natural Resource Management and Rural Development. Tropentag, Stuttgart. 
Ashworth VE and Clegg MT (2003). Microsatellite markers in avocado (Persea americana Mill.): genealogical relationships among cultivated avocado genotypes. J. Hered. 94: 407-415. http://dx.doi.org/10.1093/jhered/esg076

Bufler G and Ben-Ya'acov AD (1992). Study of avocado germplasm resources, 1988-1990. Ribosomal DNA repeat unit polymorphism in avocado. Proceedings of the 2 nd World Avocado Congress, Orange.

Campos RE, Terrazas T and López-Mata L (2007). Persea (avocados) phylogenetic analysis based on morphological characters: hypothesis of species relationships. Genet. Resour. Crop Evol. 54: 249-258. http://dx.doi.org/10.1007/ $\underline{\text { s10722-005-3808-x }}$

Chen H, Morrell PL, de la Cruz M and Clegg MT (2008). Nucleotide diversity and linkage disequilibrium in wild avocado (Persea americana Mill.). J. Hered. 99: 382-389. http://dx.doi.org/10.1093/jhered/esn016

Chen H, Morrell PL, Ashworth VE, de la Cruz M, et al. (2009). Tracing the geographic origins of major avocado cultivars. J. Hered. 100: 56-65. http://dx.doi.org/10.1093/jhered/esn068

Clegg MT, Kobayashi M and Lin JZ (1999). The use of molecular markers in the management and improvement of avocado (Persea americana Mill.). Proceedings of the IV World Avocado Congress, México. Rev. Chapingo Ser. Hortic. 5: 227231.

Cuiris-Pérez H, Guillen-Andrade H, Pedraza-Santos ME, López-Medina J, et al. (2009). Genetic variability within mexican race avocado (Persea americana Mill.) germplasm collections determined by ISSRs. Rev. Chapingo Ser. Hortic. 15: $169-175$. http://dx.doi.org/10.5154/r.rchsh.2009.15.023

Davis J, Henderson D, Kobayashi M, Clegg MT, et al. (1998). Genealogical relationships among cultivated avocado as revealed through RFLP analysis. J. Hered. 89: 319-323. http://dx.doi.org/10.1093/jhered/89.4.319

De Riek J, Calsyn E, Everaert I, Bocksteal VE, et al. (2001). AFLP based alternatives for the assessment of the distinctness, uniformity and stability of sugar beet varieties. Theor. Appl. Genet. 103: 1254-1256. http://dx.doi.org/10.1007/ $\underline{\text { s001220100710 }}$

Ellstrand NC, Lee JM, Bergh BO, Coffey MD, et al. (1986). Isozymes confirm hybrid parentage for 'G755' selections. Calif. Avocado Soc. Yearbook 70: 199-203.

Fiedler J, Bufler G and Bangerth F (1998). Genetic relationships of avocado (Persea Americana Mill.) using RAPD markers. Euphytica 101: 249-255. http://dx.doi.org/10.1023/A:1018321928400

Fontaine C, Lovett PN, Sanou H, Maley J, et al. (2004). Genetic diversity of the shea tree (Vitellaria paradoxa C.F. Gaertn), detected by RAPD and chloroplast microsatellite markers. Heredity (Edinb) 93: 639-648. http://dx.doi.org/10.1038/ si.hdy.6800591

Furnier GR, Cummings MP and Clegg MT (1990). Evolution of the avocados as revealed by DNA restriction fragment variation. J. Hered. 81: 183-188.

Galindo-Tovar ME, Arzate-Fernández AM, Ogata-Aguilar N and Landero-Torres I (2007). The avocado (Persea americana, Lauracea) crop in Mesoamerica: 10,000 years of history. Harv. Pap. Bot. 12: 325-334. http://dx.doi.org/10.3100/10434534(2007)12[325:TAPALC]2.0.CO;2

Galindo-Tovar ME, Milagro-Pérez PA, Alejandre-Rosas JA, Leyva-Ovalle OR, et al. (2011). Relaciones genéticas del aguacate (Persea americana Mill.) en siete municipios del centro de Veracruz, caracterizadas con microsatélites. Trop. Subtropical Agroecosystems 13: 339-346.

Gama-Campillo L (1994). Studies on the systematic and ethnobotany of the subgenus Persea. Doctoral thesis, University of California, Riverside.

Gilbert JE, Lewis RV, Wilkinson MJ and Caligari PDS (1999). Developing an appropriate strategy to assess genetic variability in plant germplasm collections. Theor. Appl. Genet. 98: 1125-1131. http://dx.doi.org/10.1007/s001220051176

Gutiérrez-Díez A, la Cerda JM, García-Zambrano EA, Iracheta-Donjuan L, et al. (2009). Estudio de diversidad genética del aguacate nativo en Nuevo León, México. Rev. Fitotec. Méx. 32: 9-18.

Hampl V, Pavlícek A and Flegr J (2001). Construction and bootstrap analysis of DNA fingerprinting-based phylogenetic trees with the freeware program FreeTree: application to trichomonad parasites. Int. J. Syst. Evol. Microbiol. 51: 731-735. http:// dx.doi.org/10.1099/00207713-51-3-731

Kopp L (1966). A taxonomic revision of the genus Persea in the Western Hemisphere (Persea-Lauracea). Mem. N. Y. Bot. Gard. 14: 1-117.

López LL, Saavedra GC and Rubí AM (1993). Selecciones de segregantes de aguacate (Persea americana Mill) bajo condiciones de salinidad. In. Memoria de actividades Fundación Salvador Sánchez Colín CICTAMEX-SC, México, 167-179.

López-López L, Rubí-Arriaga M, Ben-Ya'acov AD and Barrientos-Priego AF (1997). La biodiversidad del género Persea y especies afines preservados en los bancos de germoplasma del Estado de México. Rev. Chapingo Ser. Hortic. 3: 51-54. Lorea-Hernández FG (2005). Nuevas especies de Licaria, Ocotea y Persea (Laurácea) de México. Acta Bot. Mex. 71 : 61-87.

Mhameed S, Sharon D, Kaufman D, Lahav E, et al. (1997). Genetic relationships within avocado (Persea americana Mill.) cultivars and between Persea species. Theor. Appl. Genet. 94: 279-286. http://dx.doi.org/10.1007/s001220050411 
Pavlièek A, Hrdá S and Flegr J (1999). FreeTree-freeware program for construction of phylogenetic trees on the basis of distance data and bootstrap jackknife analysis of the tree robustness. Application in the RAPD analysis of genus Frenkelia. Folia Biol-Prague. 45: 97-99.

Popenoe W (1963). Early history of the avocado. Calif. Avocado Soc. Yearbook 47: 19-24.

Prevost A and Wilkinson MJ (1999). A new system of comparing PCR primers applied to ISSR fingerprinting of potato cultivars. Theor. Appl. Genet. 98: 107-112. http://dx.doi.org/10.1007/s001220051046

Reyes-Alemán JC, Valadez-Moctezuma E, Simuta-Velázco L, Barrientos-Priego AF, et al. (2013). Distinción de especies del género Persea mediante RAPD e ISSR de ADN. Rev. Mex. Cienc. Agríc 4: 517-529.

Rohwer JG, Li J, Rudolph B, Schmidt SA, et al. (2009). Is Persea (Lauraceae) monophyletic? Evidence from nuclear ribosomal ITS sequences. Taxon 58: 1153-1167.

Roldán-Ruiz I, Dendauw J, Van Bockstaele E, Depicker A, et al. (2000). AFLP Markers reveal high polymorphic rates in Ryegrasses (Loium spp). Mol. Breed. 6: 125-134. http://dx.doi.org/10.1023/A:1009680614564

Saghai-Maroof MA, Soliman KM, Jorgensen RA and Allard RW (1984). Ribosomal DNA spacer-length polymorphisms in barley: mendelian inheritance, chromosomal location, and population dynamics. Proc. Natl. Acad. Sci. USA 81: 80148018. http://dx.doi.org/10.1073/pnas.81.24.8014

Sambrook J, Fritsch EF and Maniatis T (1989). Gel electrophoresis of DNA. In: Molecular Cloning: A Laboratory Manual. 2nd edn., Vol 1. Cold Spring Harbor Laboratory Press, New York.

Scora RW, Wolstehholme BN and Lavi U (2002). Taxonomy and botany. In: The avocado: botany, production, and uses (Whiley AW, Shaffer B and Wolstenholme BN, eds.). CAB International, Wallingford, UK, 15-37.

Smith CE (1966). Archaeological evidence for selection in avocado. Econ. Bot. 20: 169-175. http://dx.doi.org/10.1007/ BF02904012

Storey WB, Bergh B and Zentmyer GA (1986). The origin, indigenous range and dissemination of the avocado. Calif. Avocado Soc. Yearbook 70: 127-133.

Valadez-Moctezuma E, Ortiz-Vásquez Q and Samah S (2014). Molecular based assessment of genetic diversity of xoconostle accessions (Opuntia spp.). Afr. J. Biotechnol. 13: 202-210. http://dx.doi.org/10.5897/AJB2013.13350

Valadez-Moctezuma E, Samah S and Luna-Páez A (2015). Genetic diversity of Opuntia spp. varieties assessed by classical marker tools (RAPD and ISSR). Plant Syst. Evol. 301: 737-747. http://dx.doi.org/10.1007/s00606-014-1112-y

Williams LO (1977a). The avocados, a synopsis of the genus Persea, subg. Persea Econ. Bot. 31: 315-320. http://dx.doi. org/10.1007/BF02866883

Williams LO (1977b). The botany of the avocado and its relatives. Proceedings of 1 st International Tropical Fruit Short Course (Sauls JW, Phillips RL and Jackson LK, eds.). University of Florida, Gainesville.

Zietkiewicz E, Rafalski A and Labuda D (1994). Genome fingerprinting by simple sequence repeat (SSR)-anchored polymerase chain reaction amplification. Genomics 20: 176-183. http://dx.doi.org/10.1006/geno.1994.1151 